[2]

\title{
Human impact on regional groundwater composition through intervention in natural flow patterns and changes in land use
}

\author{
P.P. Schot and J. van der Wal \\ Department of Environmental Studies, University of Utrecht, P.O. Box 80115, 3508 TC Utrecht, \\ Netherlands
}

(Received 1 May 1990; accepted 27 August 1991)

\section{ABSTRACT}

Schot, P.P. and van der Wal, J., 1992. Human impact on regional groundwater composition through intervention in natural flow patterns and changes in land use. J. Hydrol., 134: 297-313.

The relations between groundwater composition, land use, soil conditions and flow patterns on a regional scale are studied for the Gooi and Vechtstreek area in the Netherlands. This densely populated area consists of a glacier-created ridge with dry sand soils bordered by the Vecht and Eem River plains with wet peat and clay soils. R-mode factor analysis and Q-mode cluster analysis were applied to a set of 1349 groundwater analyses to determine the factors controlling groundwater composition and the main resulting water types.

The results indicate that groundwater composition in the study area is affected on a regional scale by human activities through changes in land use and intervention in natural flow patterns. On the ridge, ground water is recharged by precipitation, which dissolves carbonates from the matrix of the sandy aquifer. Increased solute concentrations in shallow ground water, especially of nitrate, sulphate and potassium, indicate increased pollution resulting from urbanization and increasingly intensive agricultural activity over the past decades.

In the Vecht River plain infiltration occurs as a result of drainage of polders and groundwater extraction on the ridge. Recharge occurs by precipitation and from polluted surface water to which ammonium, organic complexes and carbonic acid are added through decomposition of organic matter in the peat and clay soils. The carbonic acid results in enhanced dissolution of carbonates present in the soil and the underlying sandy aquifer. Oxygen depletion and subsequent low redox potentials result in denitrification, dissolution of manganese and iron oxides, and sulphate reduction. The flow of ground water from high-level to low-level polders causes displacement of a former stagnant brackish groundwater body under the Vecht River plain accompanied by increased mixing of fresh and brackish ground water.

\section{INTRODUCTION}

Ground water serves a number of important functions for mankind and in nature. These functions are often related to groundwater composition, which is increasingly influenced by human activities. To assess whether ground water wili maintain its piesent functionition fute, it is necessary to obtain insight 
into the factors determining groundwater composition.

Groundwater composition is determined by initial water composition during infiltration, by groundwater flow patterns and by characteristics of the aquifer. The initial water composition is primarily related to the origin of the recharge water, e.g. precipitation or surface water. During infiltration, changes in water composition may occur through natural processes or through human activities dependent on soil conditions and land use (e.g. evapotranspiration and dissolution of fertilizers).

Flow patterns determine the spatial displacement of ground water and dissolved solids through the subsurface. Groundwater flow depends on natural factors (e.g. elevation differences and lithology) and on human interventions (e.g. groundwater extraction and drainage).

The evolution of groundwater composition along the flow path is determined by physical, chemical and biological processes. The occurrence of these processes depends on the initial water composition together with the conditions in the part of the aquifer through which the water passes.

Ground water provides an important source for drinking water supply, agriculture and wetland ecosystems in the Gooi and Vechtstreek area in the Central Netherlands (Witmer, 1986; Schot et al., 1988). This paper aims at determining the main groundwater types in this region and the factors which control their composition. Groundwater composition is considered in relation to land use, soil conditions and groundwater flow patterns on a regional scale.

\section{DESCRIPTION OF THE AREA}

The study area comprises an area of $500 \mathrm{~km}^{2}$ (Fig. 1). Its main topographic feature is a sandy ridge with elevation ranging from 0 to $30 \mathrm{~m}$ above $\mathrm{m} . \mathrm{s} .1$. The ridge was created during the Saale ice age by glaciers pushing existing fluvial sediments. To the east and west the ridge is bordered by the broad and flat-lying Eem and Vecht river plains.

Land use on the ridge has changed considerably over the past century (Harten, 1976). Heath and extensively farmed arable lands have been increasingly replaced by human settlements, and agricultural land use has been intensified through application of manure and fertilizers. Nowadays, land use on the ridge consists of urban areas surrounded by woodland, heath and agricultural areas.

The naturally marshy river plains have increasingly been drained for agricultural purposes (Van Raam, 1979). Systems of connected ditches were dug to create polders in which surface water levels and hence phreatic levels are artificially controlled. Lakes present on the Vecht River plan resulted from natural causes and from peat excavation which started in the sixteenth century 


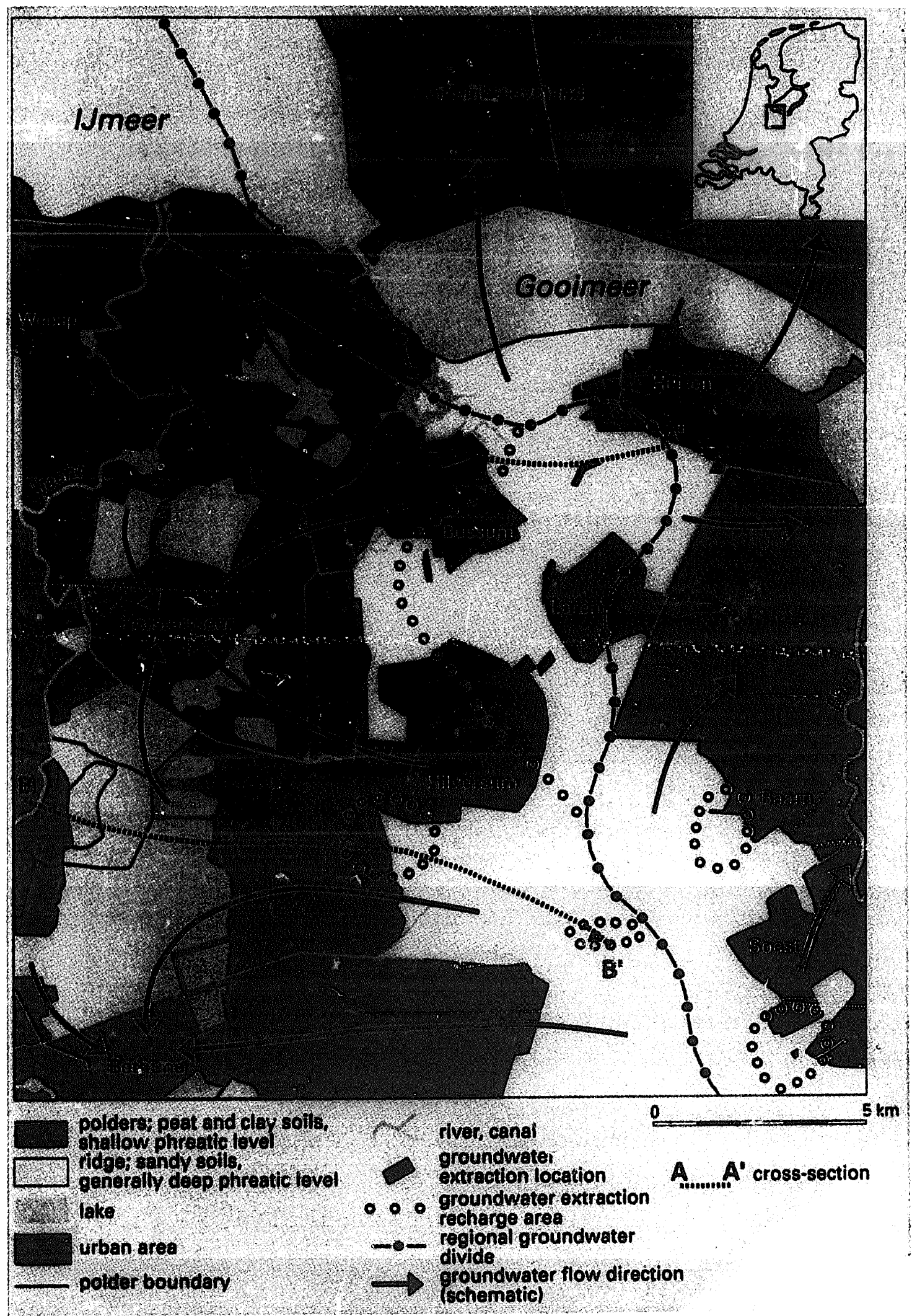

Fig. 1 Location and topography of the study area. 
and ended around 1920 (Van Raam, 1979). Nowadays the river plains are mainly used for dairy farming. The Vecht plain also contains a number of wetland nature reserves.

The main aquifer consists of thick layers of Pleistocene fluvial sands and gravels on top of semi-permeable marire clays and silty sands at 150-200 m below m.s.l. In the river plains the aquifer is in places divided into two or three subaquifers by horizontal fluvial or marine clay layers. During the Holocene a semi-confining layer was formed in the river plains on top of the Pleistocene aquifer, consisting of peat deposits locally intercalated with fluvial or marine clays (Witmer, 1989). Soils in the river plains are generally wet and rich in organic matter or clay, as opposed to the dry and sandy soils on the ridge.

Natural groundwater flow is directed from the elevated ridge towards the surrounding areas. Extraction of ground water for public drinking water supply has created a number of artificial groundwater flow systems in the ridge (Fig. 1). In the river plains the creation of polders has resulted in the development of numerous infiitration-seepage systems with groundwater flow from high-level to low-level polders. The deep polders Bethune, Horstermeer and Zuidelijk Flevoland in particular, have a strong effect on groundwater flow patterns. On the ridge recharge occurs predominantly through precipitation, whereas in the river plains recharge may consist of either precipitation or surface water (Schot, 1989; Schot and Molenaar, 1992).

Groundwater extraction from the ridge and drainage of polders has resulted in water deficits in the Vecht plain during the summer (Witmer, 1986). To maintain high water levels for agriculture the polders are supplied by Vecht River water, which contains high concentrations of sodium, chloride, calcium, magnesium and nutrients.

In the northern part of the study area a former arm of the North Sea has been dammed and changed into freshwater lakes (IJmeer, Gooimeer). As a result of the mixing of fresh ground water with seawater, part of the ground water in the northwestern part of the study area is brackish. The seawater entered the freshwater aquifer from the surface by density flow after Holocene marine transgressions (Engelen, 1981; Van der Linden and Appelo, 1988).

\section{DATA SET AND METHODS OF DATA ANALYSIS}

Data on groundwater composition are available from routine analyses by drinking water supply companies and from various geohydrological studies. Over 6000 analyses covering a time period of a century (1889-1988) have been accumulated for the purpose of this study.

Multivariate statistical techniques can be used to reduce the number of variables or cases to a smaller number, which in principle contain the same 
information on the original data. Factor analysis and cluster analysis are among the most widely used multivariate statistical techniques in hydrology (Seyhan et al., 1985). Factor analysis is usually applied in R-mode to find relations between variables. Its main objective is to rearrange the variables into a minimum number of independent factors or components that retain as much of the information stored in the original variables as possible (SAS, 1985). Cluster analysis is basically a classification technique commonly used in Q-mode to group cases (Seyhan and Keet, 1981).

In geohydrology, factor analysis has proved successful in providing information on hydrochemical processes, and cluster analysis has been applied for the purpose of grouping groundwater samples according to their overall chemical composition (Dawdy and Feth, 1967; Ashley and Lloyd, 1978; Hoogendoorn, 1983; Seyhan et al., 1985; Steinhorst and Williams, 1985; Dekkers et al., 1986, 1989; Usunoff and Guzman-Guzman, 1989; Varsanyi, 1989). In this paper, R-mode factor analysis and Q-mode cluster analysis are applied to determine the factors controlling regional groundwater composition in the study area and the main groundwater types resulting from these factors.

To obtain a suitable set of hydrochemical data for multivariate analysis the raw database was preprocessed (see the next section). For the resulting dataset a univariate statistical overview is presented and concentrations in ground water are compared with those in the mean precipitation excess. A simplified Pearson correlation coefficients matrix is presented to indicate the bivariate relations between hydrochemical parameters which form the basis for the multivariate analysis results. Factor extraction was carried out by principal components analysis. Three components were retained with eigenvalues greater than one (Kaiser, 1960). Varimax rotation was applied to obtain uncorrelated components (SAS, 1985).

Clusters were calculated by means of Ward's minimum variance method, which tends to join clusters with a small number of observations (SAS, 1985). Insight is thus obtained into water types which are significant on a regional scale. A similarity level was chosen so as to obtain a comprehensible number of six clusîers representative of the main regional groundwater types.

\section{PREPROCESSING OF HYDROCHEMICAL DATA}

The primary database contains practically all analyses of groundwater samples taken in the study area over the past century. In total, $6087^{\circ}$ analyses and 18 hydrochemical parameters were used as input, together with data on sampling location and altitude, type of well, screen depth and length and origin of the analysis.

Analyses of brackish ground water $\left(\mathrm{Cl}^{-}>300 \mathrm{mgl}^{-1}\right)$ were discarded, as 
this type of water is of no practical use. Furthermore, the large concentrations in these analyses would completely dominate the multivariate statistical analyses, thus masking the more important hydrochemical processes in fresh ground water.

For a number of wells time series of groundwater analyses are available, especially for the wells used for public drinking-water supply. To avoid spatial bias in the statistical analyses, a large number of analyses at these locations have been discarded, and care has been taken to ensure that the remaining analyses are representative of the original time series.

Many groundwater analyses contain missing values for one or several hydrochemical parameters. Missing values influence the results of the correlation and factor analyses, as coefficients across the correlation matrix are calculated from different numbers of variable pairs. Furthermore, cluster analysis cannot handle missing values. To obtain as large a set as possible of complete groundwater analyses, less important and little analysed variables were discarded (Kjeldahl-N, $\mathrm{NO}_{2}^{-}$, electrical conductivity (EC) and chemical oxygen demand). $\mathrm{PO}_{4}^{3-}$ and $\mathrm{SiO}_{2}$ were also left out of consideration, as a preliminary principal components analysis showed these variables to be independent components not correlated with other hydrochemical variables.

The remaining set of 1349 complete groundwater analyses with 12 hydrochemical parameters was used for multivariate statistical analyses. Normality of hydrochemical parameters was tested by inspection of histograms and calculation of skewness factors. Common logarithm transformation to obtain normality was necessary for all parameters except calcium, bicarbonate and $\mathrm{pH}$. Standardization was applied to obtain parameter values at the same order of magnitude.

Reliability of the data was tested by charge balance calculations using all the available parameter values. Deviations from electroneutrality are within $5 \%$ deviation for $80 \%$ of the samples and within $10 \%$ deviation for $93 \%$ of the samples. This indicates that the reliability of the data is sufficient to study the main regional hydrochemical processes and water types.

\section{RESULTS OF THE STATISTICAL ANALYSIS}

Table 1 presents an univariate statistical overview of the $1349 \times 12$ dataset. Complete analyses are available from 1967 onward but most analyses (84\%) date frcm 1978-1988. Concentrations of hydrochemical parameters in ground water are generally higher than mean concentrations in the precipitation excess (see Table 1). For sulphate, nitrate and ammonium, however, more than half the analyses show concentrations in ground water below those in the precipitation excess. Apparently, these parameters in ground water are 


\section{TABLE 1}

Univariate overview of $1349 \times 12$ dataset used for statistical analyses (concentrations in $\mathrm{mgl}^{-1}$, sampling depth in $\mathrm{m}$ below surface; concentrations in mean precipitation excess are according to Schot (1989))

\begin{tabular}{llcccccc}
\hline & Minimum & $25 \%$ & Median & $75 \%$ & Maximum & $\begin{array}{l}\text { Skewness } \\
\text { coefficient }\end{array}$ & $\begin{array}{l}\text { Mean in } \\
\text { precipitation } \\
\text { excess }\end{array}$ \\
\hline $\mathrm{pH}$ & & & & & & & \\
$\mathrm{Cl}$ & 3.7 & 6.6 & 7.3 & 7.8 & 8.7 & -1.2 & 4.0 \\
$\mathrm{HCO}_{3}$ & 6 & 15 & 30 & 59 & 290 & 2.2 & 15 \\
$\mathrm{SO}_{4}$ & 0 & 55 & 115 & 206 & 669 & 1.0 & - \\
$\mathrm{Na}$ & 0 & 6 & 18 & 37 & 349 & 3.1 & 18 \\
$\mathrm{Ca}$ & 3 & 10 & 16 & 35 & 193 & 2.1 & 9 \\
$\mathrm{Mg}$ & 1 & 28 & 45 & 66 & 198 & 0.9 & 2 \\
$\mathrm{~K}$ & 0 & 2 & 4 & 6 & 66 & 4.3 & 1 \\
$\mathrm{NO}$ & 0.2 & 0.9 & 1.5 & 3 & 290 & 18.9 & 0.6 \\
$\mathrm{NH}_{4}$ & 0 & 0.1 & 0.4 & 3.3 & 250 & 4.2 & 9 \\
Fe(-total) & 0 & 0.0 & 0.2 & 1.3 & 74 & 6.9 & 5 \\
Mn(-total) & 0 & 0.1 & 1 & 5 & 90 & 4.3 & 0.4 \\
Sampling year & 1967 & 1980 & 1983 & 1986 & 1988 & -2.7 & - \\
Sampling depth & 0.4 & 4 & 31 & 62 & 277 & 1.7 & - \\
\hline & & 0.05 & 0.21 & 0.52 & 10 & 4.9 & 0.0 \\
\hline
\end{tabular}

predominantly affected by removal mechanisms (e.g. reduction and adsorption).

Strongest correlations are observed between sodium and chloride and between calcium and bicarbonate (greater than 0.70; Table 2). Moderately strong correlations (0.5-0.7) are observed for magnesium with all four of the above parameters and between calcium and chloride. Iron correlates moderately strongly with ammonium and manganese. A relatively large number $(36 \%)$ of correlation coefficients are moderately weak $(0.3-0.5)$, which may indicate that most parameters are involved in more than one hydrochemical process.

Table 3 presents the principal components analysis results. The three components obtained account for some $71 \%$ of the observed variance. Differences in explained variance between components are relatively smali.

The results of the cluster analysis are shown in the form of a dendrogram in which Stiff diagrams (Stiff, 1951) aid interpretation in terms of groundwater types (Fig. 2). The three-dimensional form of the dendrogram allows for reproduction of similarities between clusters on different branches. Table 4 presents median parameter values per cluster. The main division between clusters is brought about by differences in total dissolved solids (TDS) 


\section{TABLE 2}

Simplified Pearson correlation matrix $(r \geqslant|0.3|)$, (strong correlations $(r \geqslant|0.7|)$ are shown in bold type, moderately strong correlations $(r \geqslant|0.5-0.7|)$ in italic type)

\begin{tabular}{|c|c|c|c|c|c|c|c|c|c|c|c|c|}
\hline & $\mathrm{pH}$ & $\mathrm{Cl}$ & $\mathrm{HCO}_{3}$ & $\mathrm{SO}_{4}$ & $\mathrm{Na}$ & $\mathrm{Ca}$ & $\mathbf{M g}$ & $\mathbf{K}$ & $\mathrm{NO}_{3}$ & $\mathbf{N H}_{4}$ & $\mathrm{Fe}$ & Mn \\
\hline $\mathrm{pH}$ & . & & & & & & & & & & & \\
\hline $\mathrm{Cl}$ & & ${ }^{\circ}$ & & & & & & & & & & \\
\hline $\mathrm{HCO}_{3}$ & 0.31 & 0.38 & . & & & & & & & & & \\
\hline $\mathrm{SO}_{4}$ & & & 0.31 & . & & & & & & & & \\
\hline $\mathrm{Na}$ & & 0.94 & 0.43 & & . & & & & & & & \\
\hline $\mathrm{Ca}$ & & 0.50 & 0.83 & & 0.49 & . & & & & & & \\
\hline $\mathbf{M g}$ & & 0.56 & 0.54 & & 0.56 & 0.58 & & & & & & \\
\hline K & -0.34 & 0.42 & & 0.35 & 0.43 & & 0.49 & . & & & & \\
\hline $\mathrm{NO}_{3}$ & & & -0.36 & 0.41 & & & & & $\cdot$ & & & \\
\hline $\mathrm{NH}_{4}$ & -0.38 & 0.37 & 0.35 & & 0.37 & & 0.35 & 0.40 & & . & & \\
\hline $\mathrm{Fe}$ & -0.33 & & 0.35 & -0.34 & & & & & -0.46 & 0.60 & & \\
\hline $\mathrm{Mn}$ & -0.37 & & & & & & 0.30 & & -0.30 & 0.48 & 0.53 & \\
\hline
\end{tabular}

\section{TABLE 3}

Results of the principal components factor analysis with Varimax rotation (only component loadings $\geqslant|0.5|$ included)

\begin{tabular}{lccc}
\hline & $\mathrm{Fl}$ & $\mathrm{F2}$ & $\mathrm{F3}$ \\
\hline $\mathrm{pH}$ & & -0.76 & \\
$\mathrm{Cl}$ & 0.78 & & \\
$\mathrm{HCO}_{3}$ & 0.80 & & 0.78 \\
$\mathrm{SO}_{4}$ & & & \\
$\mathrm{Na}$ & 0.78 & & \\
$\mathrm{Ca}$ & 0.87 & & \\
$\mathrm{Mg}$ & 0.76 & & 0.59 \\
$\mathrm{~K}$ & & & 0.71 \\
$\mathrm{NO}$ & & 0.77 & \\
$\mathrm{NH}$ & & 0.75 & \\
Fe(-total) & & 0.69 & \\
$\mathrm{Mn}$ (-total) & & 2.63 & 71.5 \\
Explained variance & 3.58 & 51.8 & \\
Cumulative variance (\%) & 29.9 & & \\
\hline
\end{tabular}




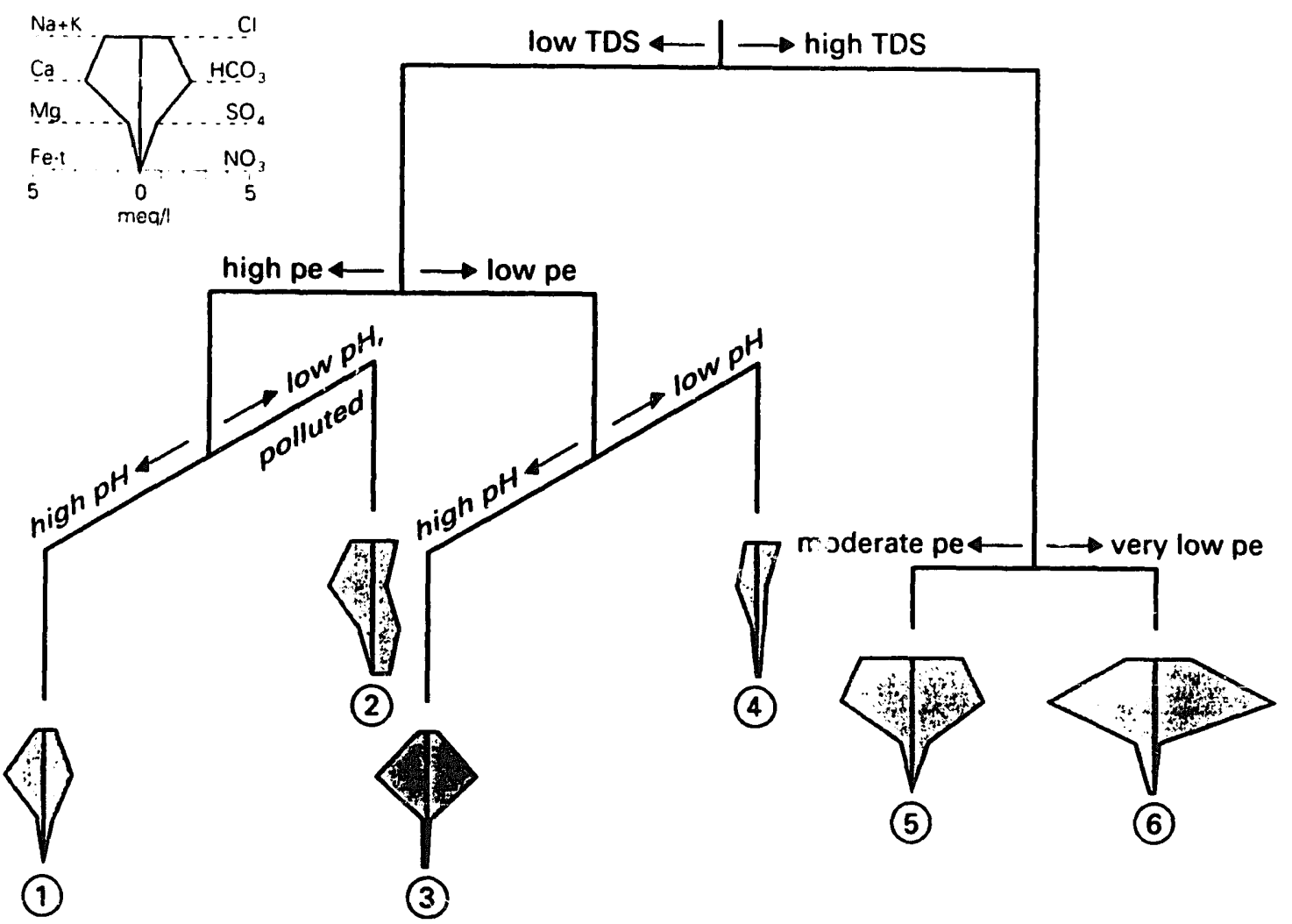

Fig. 2 Three dimensional dendrogram of Ward's method cluster analysis. Cluster numbers encircled. Stiff diagrams and texts indicating main divisions between clusters are based on median concentrations per cluster (see Table 4).

reflected in the EC. Further subdivisions result from differences in redox potential $(\mathrm{pE})$, acidity $(\mathrm{pH})$ and the presence of pollutants $\left(\mathrm{NO}_{3}^{-}, \mathrm{SO}_{4}^{2-}\right.$ and $\mathbf{K}^{+}$).

\section{INTERPRETATION OF PRINCIPAL COMPONENTS AND CLUSTERS}

\section{Principal components}

Principal components are interpreted in terms of factors determining groundwater composition by considering variables with a component loading outside the range from -0.5 to 0.5 (Table 3 ). The combination of calcium, bicarbonate and magnesium in component 1 points to dissolution of carbonates, whereas sodium, choride and magnesium suggest mixing with seawater or infiltration of surface water influenced by supplemention from Vecht River water. Increased calcium, magnesium, sodium and chloride concentrations may also indicate recharge by poliuted water from agricultural lands or from urban areas. 


\section{TABLE 4}

Median values for clusters, arranged according to principal components model (concentrations in $\mathrm{mgl}^{-1}, \mathrm{EC}$ in $\mu \mathrm{S} \mathrm{cm}^{-1}$, depth in metres below surface; highest concentration per variable in bold type)

\begin{tabular}{llcccccc}
\hline & & Clus1 & Clus2 & Clus3 & Clus4 & Clus5 & Clus6 \\
\hline $\mathrm{F} 1$ & $\mathrm{Ca}$ & 34 & 39 & 43 & 17 & 66 & $\mathbf{9 7}$ \\
& $\mathrm{HCO}$ & 79 & 29 & 130 & 19 & 194 & $\mathbf{3 4 6}$ \\
& $\mathrm{Na}$ & 11 & 19 & 10 & 16 & $\mathbf{5 5}$ & 32 \\
$\mathrm{Ci}$ & 18 & 35 & 15 & 28 & $\mathbf{8 0}$ & 58 \\
$\mathrm{Mg}$ & 2 & 7 & 3 & 3 & 6 & $\mathbf{8}$ \\
$\mathrm{F} 2$ & $\mathrm{NH}_{4}$ & 0.0 & 0.1 & 0.3 & 1.8 & 0.8 & $\mathbf{3 . 3}$ \\
& Fe(-total) & 0.0 & 0.2 & 3.5 & 2.6 & 1.3 & $\mathbf{1 2}$ \\
& Mn(-total) & 0.03 & 0.13 & 0.28 & 0.37 & 0.41 & $\mathbf{0 . 5 0}$ \\
& pH & 7.9 & 6.2 & 7.3 & $\mathbf{5 . 7}$ & 7.1 & 7.2 \\
$\mathrm{~F} 3$ & $\mathrm{SO}$ S $_{4}$ & 21 & $\mathbf{5 1}$ & 6 & 16 & 34 & 3 \\
& $\mathrm{NO}{ }_{3}$ & 3.1 & $\mathbf{5 0 . 7}$ & 0.2 & 0.4 & .0 .3 & 0.1 \\
& $\mathrm{~K}$ & 0.9 & $\mathbf{6 . 4}$ & 1.0 & 2.0 & 2.4 & 2.1 \\
& EC & 220 & 403 & 277 & 232 & 590 & 674 \\
& Observations & 297 & 130 & 351 & 128 & 356 & 87 \\
Mean depth & 46 & 15 & 76 & 2.5 & 39 & 33 \\
\hline
\end{tabular}

Component 2 represents presence of organic matter. Mineralization results in production of ammonium and carbonic acid and consequently high loadings for ammonium and $\mathrm{pH}$ (negative). Dissolved organic complexes form an important source for iron and manganese. Additionally, iron and manganese oxides may be used as oxidants of organic matter and dissolve in this process. In the river plains organic matter is abundantly present in the Holocene peat and clay soils and also to a lesser degree in the fluvial and marine clay layers dividing the main aquifer into subaquifers. In the ridge organic matter is present in organic pollution from leaking sewage, cesspools and manure.

Sulphate, nitrate and potassium characterize component 3 and point to pollution from various sources, such as manure, fertilizer and sewage water. In a number of cases, component 3 indicates infiltration of polluted surface water or influence of brackish water (high sulphate and potassium, and low nitrate).

\section{Clusters}

The regional distribution of groundwater types is shown in maps for each 
cluster. The mutual relationship between clusters is displayed along two cross-sections from the ridge to the Vecht River parallel to the groundwater flow direction (Fig. 1). Maps and cross-sections are used to determine the relation of groundwater composition to land use, soil conditions and groundwater flow patterns. Groundwater flow patterns along the cross-sections are based on Schot (1990) for section $A-A^{\prime}$ and on Hettling (1985) and Schot (1989) and P.P. Schot (unpublished isotope lata, 1988) for section B-B'.

Clusters 1 and 2 are almost exclusively found on or close to the ridge, in accordance with their oxidized character (Figs. 3 and 4). Cluster 1 contains analyses of relatively unpolluted, calcium bicarbonate water generally found under heath. Cluster 2 represents typical polluted calcium sulphate water types, with high sulphate, nitrate, potassium and magnesium concentrations, located in or near urban areas on the ridge and in agricultural areas in the transition zone to the Vecht plain. The average depth of cluster 2 samples is low compared with that of cluster 1 samples (respectively $15 \mathrm{~m}$ and $46 \mathrm{~m}$ below ground surface), as is also clear from the cross-sections. This indicates increased groundwater pollution during recent years. A general evolution of cluster 2 into cluster 1 water types by hydrochemical processes is ruled out by the low natural chloride concentration of cluster 1 .

On the ridge, cluster 3 reflects rather deep, unpolluted ground water which may have evolved out of cluster 1 water types during prolonged flow. Increased manganese and iron contents and low nitrate and sulphate contents point to a lowered redox potentiai brought about by oxidation of dissolved organic matter. This is consistent with small but significant increases in amrnonium and in calcium, bicarbonate and magnesium after $\mathrm{CO}_{2}$ production. In the river plains, cluster 3 water types reflect old ground water originating from the ridge or shallow samples taken in reedlands (Fig. 4). These reedland samples consist of local precipitation neutralized by solution of calcium carbonate present in the soil.

Cluster 4 represents acid (median $\mathrm{pH}$ is 5.7 ), moderately reduced analyses mostly from the Vecht River plain (Fig 3). The average sample depth is $2.5 \mathrm{~m}$, with a narrow range, indicating water from peat layers. Mineralization results in production of $\mathrm{CO}_{2}, \mathrm{H}^{+}$, ammonium and organic complexes, and possibly manganese and iron dissolution under relatively low $\mathrm{pE}$ conditions. Mediar. chloride contents equal that in precipitation with open water evaporation (concentration of 6.1; Schet, 1989), implying an average crop factor for the wetland vegetation of close to 1.0 .

Clusters 5 and 6 display high TDS contents, especially of chloride, sodium, calcium and bicarbonate. Differences in redox potential result in higher iron, calcium and bicarbonate, and lower sulphate contents in cluster 6 than in cluster 5 . Chloride concentrations point to recharge by sources other than precipitation. 

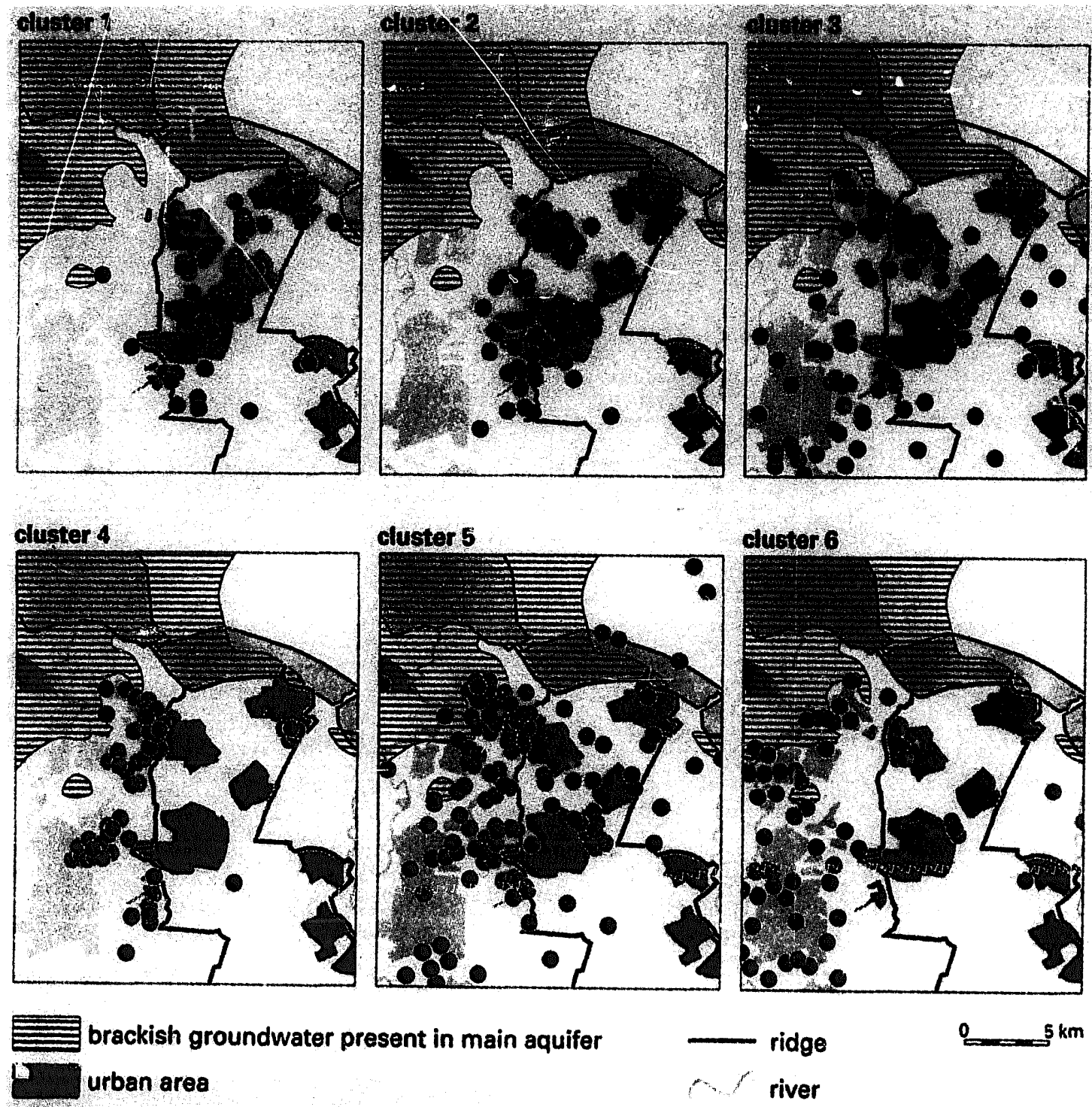

14. 1 lake

- groundwater sample with specified cluster number

Fig. 3 Spatial distribution of clusters.

Cluster 5 water types may originate from pollution on the ridge or in the transition zone to the Vecht plain, from infiltration of surface water in the Vecht plain and from mixing with brackish water (Figs. 3 and 4). Cluster 6 samples are primarily found in the western part of the Vecht plain, after recharge of surface water through peat layers. Mineralization produces organic complexes, ammonium and $\mathrm{CO}_{2}$, followed by enhanced dissolution of carbonates. Low-pE conditions result in sulphate reduction and in dissolution of iron and manganese oxides. 

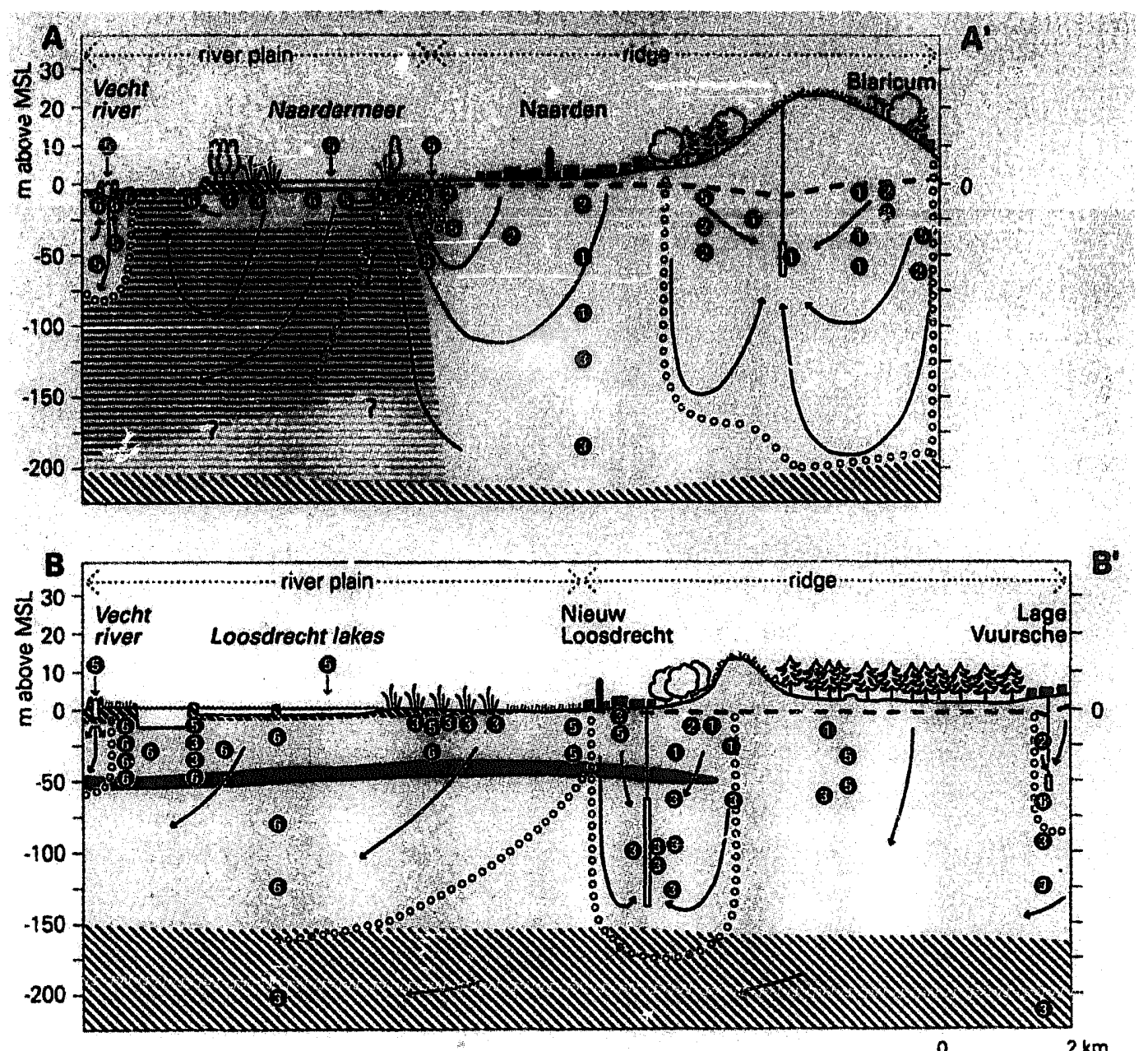

Holocene:

peat \& fluvial/lacustrine clay $2 \mathrm{~km}$

Pleistocene:

fluvial sand/gravel

2. fluvial clay

marine clay \& silty sands

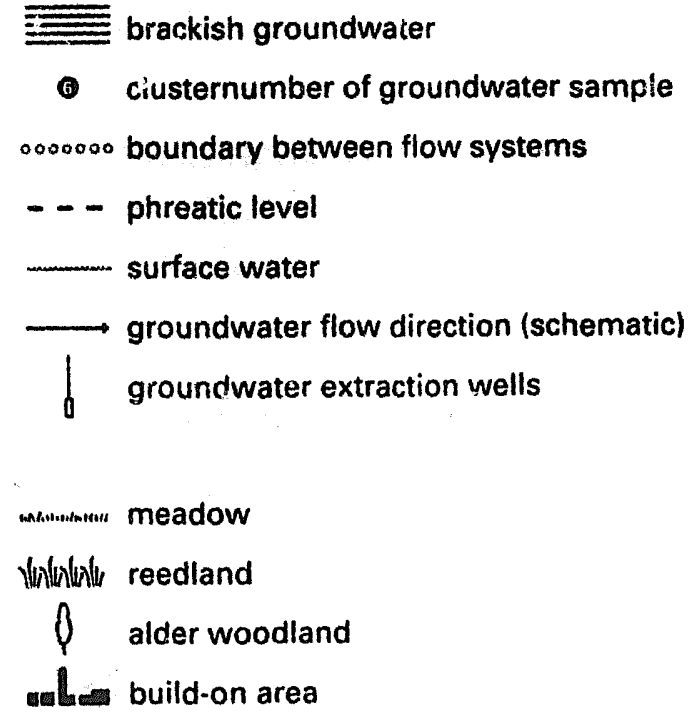

Fig. 4 Distribution of clusters along cross-sections $A-A^{\prime}$ and $B-B^{\prime}$ in relation to land use and groundwater flow patterns (for location see Fig. 1). 


\section{DISCUSSION}

The results of the applied multivariate statistical techniques provide insight into the factors controlling regional groundwater composition in the Gooi and Vechtstreek area and an overview of the main resulting groundwater types. Groundwater composition is primarily determined by the following factors.

(1) Dissolution of carbonates. This hydrochemical process predominantly controls calcium and bicarbonate concentrations and, to a lesser degree, magnesium concentrations. The six clusters all have calcium as the major cation whereas bicarbonate is the major anion for four clusters.

(2) Decomposition of organic matter. Mineralization produces ammonium, carbonic acid and organic complexes. Oxygen depletion may result in denitrification, dissolution of manganese and iron oxides, and finally sulphate reduction.

(3) Pollution. Application of manure and fertilizers, leaking sewage and cesspools are the main sources of high nitrate, sulphate and potassium concentrations.

(4) Recharge of surface water affected by Vecht River water. This is the main source for the high sodium and chloride concentrations in fresh groundwater in the western part of the study area.

(5) Mixing of fresh and brackish ground water.

Plotting the spatial distribution of clusters allows consideration of groundwater composition in relation to land use, soil conditions and flow patterns. The cluster maps do not always seem to be straightforward and are only roughly consistent with what could be expected on the basis of regional soil conditions and groundwater flow patterns (Fig. 1). This is primarily caused by spatial differences in land use, which cannot be displayed in the necessary detail with the map scale used. On the other hand, genetically different groundwater types may be grouped in the same cluster. Cluster 5, for example, contains samples of rather dilute groundwater recharged on the ridge, of ground water affected by infiltration of surface water in the Vecht plain and of mixed fresh-brackish ground water. The cross-sections allow for a more detailed comparison of groundwater composition, land use and groundwater flow patterns. Moreover, they provide insight into the evolution of groundwater composition with depth.

Human activities considerably affect groundwater composition in the study area, both directly through different forms of land use and indirectly through intervention in natural groundwater flow patterns. Pollution from various sources is an obvious example of a direct influence and is noticeable especially on the ridge, where population density is high. Polluted water types are 
generally found in relatively shallow ground water, indicating increased pollution resulting from changes in land use (urbanization and increased agricultural intensity) over the past decades.

Indirect effects are noticeable mainly in the Vecht river plain. Groundwater extraction has resulted in a decreased supply of ground water from the ridge, and differences in polder water levels have caused groundwater flow from high-level to low-level polders. These factors have resulted in seepage areas changing into infiltration areas, starting mineralization of peat layers and associated secondary hydrochemical processes such as denitrification, dissolution of maganese and iron, and sulphate reduction. Groundwater extraction and drainage have necessitated supplementing the water supply of polders and natural wetlands with polluted Vecht water. Subsequent infiltration of this water has resulted in ground water with a Vecht water-like composition. Finally, the flow of ground water from high-level to low-level polders has caused displacement of the former stagnant brackish groundwater body under the Vecht River plain (Schot and Molenaar, 1992), resulting in increased mixing of fresh and brackish ground water.

Taking an overall view, it is concluded that human activities affect groundwater composition in the study area on a regional scale.

High calcium and bicarbonate concentrations deserve special attention. Dissolution of carbonates is a naturally occurring process, as is shown by unpolluted water types in the ridge (clusters 1 and 3). Calcium and bicarbonate concentrations generally increase with depth as a result of addition of carbonic acid from mineralization of organic matter present in small clay lenses in the sandy aquifer (cluster 3). Ground water from the ridge flows towards the adjacent low-lying areas. High calcium and bicarbonate concentrations in Dutch river plains are therefore often interpreted as indicators for seepage of ground water recharged in elevated sandy areas.

Hoogendoorn (1983) suggested that high calcium and bicarbonate concentrations in areas with shallow water tables may not be caused by seepage of old, 'mature' ground water but rather by local recharge through a biologically active soil. The high soil $\mathrm{CO}_{2}$ pressure caused by mineralization of organic matter then consitutes the driving force for strong dissolution of calcium bicarbonate.

In the study area, cluster 6 shows the highest calcium and bicarbonate concentrations. The low $\mathrm{pE}$ conditicns and high ammonium concentration point to mineralization processes. Thus, for the study area, the highest calcium and bicarbonate concentrations are indeed associated with local recharge through peat layers, as suggested by Hoogendoorn. On the other hand, chloride concentrations in cluster 6 indicate recharge by surface 
water affected by added Vecht River water, which displays high calcium and bicarbonate conients even before infiltration.

Definite conclusions about the interpretation of calcium and bicarbonate concentrations, and likewise of other chemical parameters, must be based on a more detailed, quantitative study in which the vertical distribution of water types is related to lithology, past and current groundwater flow patterns, and changes in infiltration water quality over time. Such a study of hydrochemical processes in wetlands of the Vecht River plain has been described by Schot and Wassen (1992).

\section{ACKNOWLEDGEMENTS}

Groundwater analysis data were provided by the water supply companies PWN, WMN and GWA, The National Institute of Public Health and Environmental Protection, the municipality of Hilversum, the Province of Noord-Holland, the Free University Amsterdam and the University of Utrecht. M.C.H. Witmer is thanked for performing the tedious job of building the original digital data base which was later extended by the first author. A.W.M. Verkroost, C.H. van der Weijden, I. Simmers and C.A.J. Appelo provided useful suggestions for improvement of the manuscript.

\section{REFERENCES}

Ashiley, R.P. and Lloyd, J.W., 1978. An example of the use of factor analysis and cluster analysis in groundwater chemistry interpretation. J. Hydrol., 39: 355-364.

Dawdy, D.R. and Feth, J.H., 1967. Application of factor analysis in the study of chemistry of groundwater quality, Mojave River Valley, California. Water Resour. Res., 3(2): 505-510.

Dekkers, M.J., Vriend, S.P., van der Weijden, C.H. and van Gaans, P.F.M., 1986. The São Pedro do Sul Granite, Portugal: hydrogeochemistry related to the prospection of uranium. Uranium, 2: 261-277.

Dekkers, M.J., Vriend, S.P., van der Weijden, C.H. and van Gaans, P.F.M. 1989. Uranium anomaly evaluation in groundwaters: a hydrogeoshemical study in the Nisa region, Portugal. Appl. Geochem. 4: 375-394.

Engelen, G.B., 1981. The Quaternary sequence of water systems in the western part of the Netherlands. Moderne Rekenmethoden (zoet-zout groundwater), Stichting Postakademiale Vorming Gezondheidstechniek, Delft.

Harten, J.D.H., 1976. De genese van het Gooise cultuurlandschap. Geogr. Tijdschr., 10: 93-116.

Hettling, H.K., 1985. Isotopic Groundwater Study of the Loosdrecht Lakes Area (The Netherlands). Free University, Amsterdam. 55 pp.

Hoogendoorn, J.H., 1983. Hydrochemie Oost-Nederland. Dienst Grondwaterverkenning TNO, Delft-Oosterwolde.

SAS, 1985. SAS User's Guide: Statist cs. Version 5 Edition. SAS Institute Inc., Cary, NC, 956 pp. 
Schot, P.P., 1989. Grondwatersystemen en grondwaterkwaliteit in Het Gooi en randgebieden. Interfacultaire Vakgroep Milieukunde, Rijksuniversiteit Utrecht, 44 pp.

Schot, P.P., 1990. Groundwater systems analysis of the Naardermeer wetland, the Netherlands. In: E.S. Simpson and J.M. Sharp (Editors), Selected Papers from the 28th Int. Geol. Congr., Washington, DC, 1989. IAH Selected Papers on Hydrology, Hannover, Vol. 1, pp. 257-269.

Schot, P.P. and Molenaar, A., 1992. Regional changes in groundwater flow patterns and effects on groundwater composition. J. Hydrol., 130: 151-170.

Schot, P.P. and Wassen, M.J., 1992. Calcium concentrations in wetland groundwater in relation to water sources and soil conditions in the recharge area. J. Hydrol., submitted.

Schot, P.P., Barendregt, A. and Wassen, M.J., 1988. Hydrology of the Wetland Naardermeer: Influence of the surrounding area and impact on vegetation. Agric. Water Manage., 14: 459-470.

Seyhan, E. and Keet, B., 1981. Multivariate statistical analysis (part 1), Application to hydromopho-metrical data (case-study; Ahr River basin, Bolzano, Italy). Aqua-VU series A, No. 8. Rodopi, Amsterdam.

Seyhan, E., van de Griend, A.A. and Engelen, G.B., 1985. Multivariate analysis and interpretation of the hydrochemistry of a dolomite reef aquifer, Northern Italy. Water Resour. Res., 21: 1010-1024.

Steinhorst, R.K. and Williams, R.E., 1985. Discrimination of groundwater sources using cluster analysis, MANOVA, canonical analysis and discriminant analysis. Water Resour. Res., 21: 1149-1156.

Stiff, Jr., H.A. 1951. The interpretation of chemical water analysis by means of patterns. J. Petrol. Technol., 3(10): 15-17.

Usunoff, E.J. and Guzman-Guzman, A., 1989. Multivariate analysis in hydrochemistry: an example of the use of factor and correspondence analyses. Groundwater, 27: 27-34.

Van der Linden, F.J. and Appelo, C.A.J., 1988. Hydrochemie en herkomst van zout kwelwater in de Horstermeerpolder. $\mathrm{H}_{2} \mathrm{O}, 22: 71-75$.

Van Raam, J., 1979. Tussen Gooi en Vecht, milieukundig onderzoek van de Vechtstreek, deel 3. Gewest Gooi en Vechtstreek, Hilversum/Rijksuniversiteit Utrecht, 88 pp.

Varsanyi, I., 1989. Tracing groundwater flow using chemical data. Hydrol. Sci. J., 34: 3-6.

Witmer, M.C.H., 1986. Management of groundwater and surface water resources in the infiltration area "Het Goci" and adjacent wetlands. In: S.M. Gorelich (Editor), Conjuctive Water Use. IAHS Publ. 156, Wallingford, Oxon, pp. 537-547.

Witmer, M.C.H., 1989. Integral water management at regional level. An environmental study of the Gooi and the Vechtstreek. Ph.D. Dissertation Rijks Universiteit Utrecht, 's-Gravenhage, $172 \mathrm{pp}$. 